\title{
Validity of Nursing Outcomes Classification health promotion behavior scale in college students
}

\author{
Validade da escala de comportamento de promoção da saúde da Nursing Outcomes Classification em universitários
}

Validad de la escala de conducta de promoción de la salud de la Nursing Outcomes Classification en universitarios

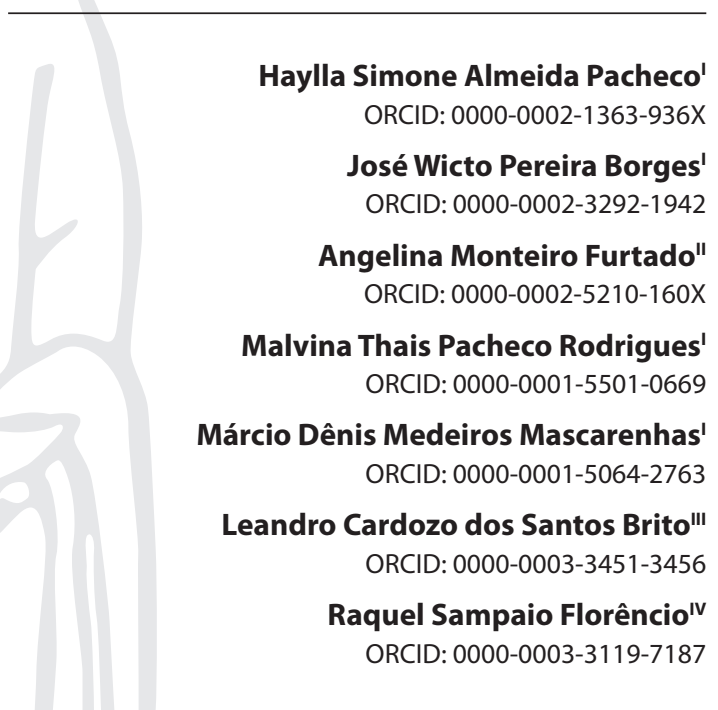

' Universidade Federal do Piauí. Teresina, Piauí, Brazil. "Universidade Federal do Piauí. Floriano, Piauí, Brazil.

I" Universidade Federal do Piauí. Parnaíba, Piauí, Brazil. "v Universidade Estadual do Ceará. Fortaleza, Ceará, Brazil.

How to cite this article: Pacheco HSA, Borges JWP, Furtado AM, Rodrigues MTP, Mascarenhas MDM, Brito LCS, et al. Validity of Nursing Outcomes Classification health promotion behavior scale in college students. Rev Bras Enferm. 2020;73(Suppl 5):e20200126. doi: http://dx.doi.org/10.1590/0034-7167-2020-0126

\section{Corresponding author:}

Haylla Simone Almeida Pacheco E-mail: haylla.simone_12@hotmail.com

EDITOR IN CHIEF: Antonio José De Almeida Filho ASSOCIATE EDITOR: Ana Fátima Fernandes

\section{ABSTRACT}

Objective: to verify the reliability and validity of the health promotion behavior scale, of the Nursing Outcomes Classification, in university students. Method: methodological study carried out with 324 university students from a federal institution, based in a city in the Northeast of Brazil. Internal consistency was verified using Cronbach's alpha and item-total correlation. Validity was performed through exploratory factor analysis via main components. Results: the scale showed a Cronbach's alpha of 0.83 , showing good reliability. The item-total correlations remained above 0.3 for most items, only items $01,13,19$ and 20 were below this mark. In the exploratory factor analysis, two components were extracted whose variances explained $44.54 \%$ of the instrument's composition. Conclusion: the health promotion behavior scale showed good reliability and validity, demonstrating that it can be applied to the population of university students.

Descriptors: Health Behavior; Health Promotion; Standardized Nursing Terminology; Student Health Services; Validation Study.

\section{RESUMO}

Objetivo: verificar a confiabilidade e validade da escala de comportamento de promoção da saúde, da Nursing Outcomes Classification, em estudantes universitários. Método: estudo metodológico realizado com 324 universitários de uma instituição federal, sediada em uma cidade do Nordeste brasileiro. A consistência interna foi verificada por meio do alfa de Cronbach e correlação item-total. A validade foi realizada mediante análise fatorial exploratória via componentes principais. Resultados: a escala apresentou alfa de Cronbach de 0,83 , demonstrando boa confiabilidade. As correlações item-total mantiveram-se acima de 0,3 para a maioria dos itens, apenas os itens $01,13,19$ e 20 ficaram abaixo dessa marca. $\mathrm{Na}$ análise fatorial exploratória, foram extraídos dois componentes cujas variâncias explicaram $44,54 \%$ da composição do instrumento. Conclusão: a escala de comportamento de promoção da saúde apresentou boa confiabilidade e validade, demonstrando que pode ser aplicada à população de universitários.

Descritores: Comportamentos Relacionados com a Saúde; Promoção da Saúde; Terminologia Padronizada em Enfermagem; Serviços de Saúde para Estudantes; Estudo de Validação.

\section{RESUMEN}

Objetivo: verificar la confiabilidad y la validad de la escala de conducta de promoción de la salud, de la Nursing Outcomes Classification, en estudiantes universitarios. Métodos: estudio metodológico realizado con 324 universitarios de una institución federal, con sede en una ciudad del Noreste brasileño. La consistencia interna ha sido verificada por medio del alfa de Cronbach y correlación ítem-total. La validad ha sido realizada mediante análisis factorial exploratorio vía componentes principales. Resultados: la escala presentó alfa de Cronbach de 0,83 , demostrando buena confiabilidad. Las correlaciones ítem-total se mantuvieron arriba de 0,3 para la mayoría de los ítems $01,13,19$ y 20 quedaron abajo de esa marca. En el análisis factorial exploratorio, han sido extraídos dos componentes cuyas las desviaciones explicaron $44,54 \%$ de la composición del instrumento. Conclusión: la escala de conducta de promoción de la salud presentó buena confiabilidad y validad, demostrando que puede ser aplicada a la población de universitarios.

Descriptores: Conductas Relacionadas a la Salud; Promoción de la Salud; Terminología Estandarizada en Enfermería; Servicios de Salud para Estudiantes; Estudio de Validación. 


\section{INTRODUCTION}

Entrance to the university is considered a complex phase for many students, since, for most of them, it is the first moment when they take responsibility for housing, food and also for the management of their finances, impacting their lifestyle and favoring health risk behaviors ${ }^{(1)}$. Considering these scenarios, health services need to be sensitive, helping to reorient the focus of assistance to student well-being with an emphasis on health promotion ${ }^{(2)}$.

Primary Care Nurses need to enter the university space, undertaking health promotion actions, aiming at the development of potentials in individuals and enabling opportunities for knowledge and control over determining factors ${ }^{(3-4)}$. Guiding health-promoting behaviors as a lifestyle component is an expression of the human tendency, with a focus on increasing individual well-being, for updating and personal fulfilment, which should be objects of nursing care ${ }^{(5-6)}$. With this purpose, a research was developed to identify the nurses' competences in the face of health promotion, which showed that this professional emphasizes planning, however the evaluation is still below expectations ${ }^{(7)}$.

In this sense, it represents an alternative to qualify nursing care the use of standardized language systems, such as Nursing Outcomes Classification (NOC) ${ }^{(8)}$. The use of the NOC makes it possible to identify changes in health status through different indicators and their scores over time, allowing to monitor the improvement, worsening or stagnation of the patient's state during a period of care $^{(9)}$. Thus, considering the university environment as a conducive place to the promotion of educational actions, through nursing interventions, the use of the Nursing Outcomes (NO) related to Health Promotion Behavior allows to measure the panorama of lifestyle and well-being. university students and monitor the effectiveness of interventions based on their indicators.

The Health Promotion Behavior Scale (HPLP) belongs to the "Health beliefs" class of the "Health knowledge and behavior" domain ${ }^{(8-9)}$. The HPLP, with its 23 indicators, was built using the Health Promoting Lifestyle Profile II (HPLP II), composed of 52 items arranged in six dimensions, obtaining good internal consistency with Cronbach's alpha of 0.94 and construct validity confirming its six factors ${ }^{(10-11)}$. However, the construction of HPLP, based on HPLP-II, does not guarantee the same validity and reliability as the original instrument, leaving an open field for research.

Furthermore, although the NOC encourages studies on the reliability and validity of its scales, investigations of this scope on HPLP were not found in the health sciences databases. Thus, one of the biggest challenges in research involving results sensitive to nursing is related to the development and validity of appropriate instruments for its evaluation ${ }^{(12)}$.

The use of nursing classifications means advances both in the quality of records and in a practice with its own scientific basis, on the foundation of reliable and valid technologies. The validation of results directly contributes to the Nursing Process, from the planning stages to the evaluation, by choosing relevant indicators for the context in which they will be used, discarding non-critical indicators for the public in question ${ }^{(13)}$.

Thus, the HPLP is formed by potential indicators for the evaluation of the university public, which is constituted, as a rule, by adults and young people vulnerable to the decline of well-being. However, the empirical potential of the indicators needs to be demonstrated in evidence of validity, aiming at the adequate assessment of this care context. In this sense, the question is: What is the evidence of validity and reliability of HPLP as a care technology in university students?

Answering this question brings advances to the taxonomy of the NOC, since it contributes to the elucidation of the indicators that are valid in the specific context of care, and can contribute with elements for the maintenance and review of this NO. Still, it offers potential to assist in the elaboration of Nursing Processes applied to university students, with goals for indicators that have low scores on the scale.

\section{OBJECTIVE}

To verify the reliability and validity of the Health Promotion Behavior Scale (HPLP), from NOC, in university students.

\section{METHODS}

\section{Ethical aspects}

The study was approved by the Research Ethics Committee of the Federal University of Piauí, Campus Ministro Petrônio Portela, in line with the recommendations of Resolution 466/2012.

\section{Design, study location and period}

Methodological study to validate the HPLP of the NOC, developed from May 2016 to December 2017, in a public Higher Education Institution (HEI), based in the city of Floriano, Piauí.

In the Center-South of Piauí, HEl is located, in which five oncampus undergraduate courses operate: Bachelor of Nursing, Bachelor of Administration, Full Degree in Biological Sciences, Full Degree in Pedagogy and Licentiate in Education in the Field.

\section{Population and sample}

The study population comprises 1,420 university students with active enrolment in the five courses, being distributed as follows: 254 for Nursing, 330 for Administration, 279 for Biology, 357 for Education and 200 for Education in the Field.

The sample was calculated using the formula for finite population (5\% error, 95\% confidence interval and 50\% prevalence), resulting in a total of 333 students when an additional 10\% was added to the sample. Thus, the prevalence of $50 \%$ was used in the hypothesis that at least half of the university population would exhibit health-promoting behavior. In the end, due to the losses already foreseen, the sample resulted in 324 university students, adopting as inclusion criteria being 18 years of age or older and having an active enrolment in the HEl during the interview period. Pregnant women were excluded from this contingent due to behavioral changes inherent to the gestational period. The option to use the formula for the finite population, as well as the guarantee of no losses, was carried out to support further analysis of intervening factors in the nursing outcome and health promotion behavior. 


\section{Study protocol}

Data was collected from October 2016 to September 2017. The approach was carried out in the HEl corridors with the presentation of the researcher, explanation of the research and its objectives, as well as the importance of the study. Each university student was invited to go to a room reserved for research, and an invitation was then made to participate in the study. Those who agreed signed the Free and Informed Consent Form - FICF, provided in two copies (one for the interviewee and one for the researcher), guaranteeing the participant the right to withdraw from the research at any time.

Data collection took place through an individual clinical interview, in a reserved room to maintain the student's privacy. During the interview, the researcher collected sociodemographic data and applied the HPLP indicators using a form. The university students were asked about each indicator selected for the study, using the operational definitions previously elaborated regarding this. Thus, the magnitude of the presence of the investigated behavior in each indicator was placed on the Likert scale, at the level determined by the university student. After positioning the behavior levels in each indicator, guidelines for healthy behavior were carried out.

The original HPLP has 23 indicators accompanied by a fivepoint adjective scale (" 1 - never demonstrated" to " 5 - consistently demonstrated"), inserted in the domain of Health knowledge and behaviors, referring to personal actions to maintain or increase the well-being. However, we chose to use 20 indicators to compose the data collection instrument in this research, whose investigators were university students chosen based on the public's evaluation to which the result is intended ${ }^{(9)}$. Thus, the option was not to use the indicators "Monitoring the environment with respect to risks", "Support for healthy public policies" and "Obtaining regular check-ups". Such exclusion was made to avoid confusion bias, since the excluded indicators are similar to others already present in the original scale, namely: "Monitoring personal behavior regarding risks", "Use of social support to promote health" and "Obtaining recommended health assessments".

After selecting the indicators, the researchers in charge constructed the operational definitions for each one, based on the literature and the authors' experiences. It is worth mentioning that the operational definitions were elaborated to discriminate the evaluation of the indicator and establish the rules for clinical evaluation, taking into account the magnitude of the five-point Likert scale ${ }^{(10)}$.

\section{Analysis of results and statistics}

The data were organized in an electronic spreadsheet and exported to free statistical programs: Factor, version 10.10.01, developed by Rovira i Virgili University; and R, version 3.6.2. The verification of the psychometric behavior of the scale was performed using measures of reliability and validity.

The reliability analysis was verified in terms of the instrument's internal consistency, using Cronbach's alpha coefficient and item-total correlation, using the "Psych" statistical package ${ }^{(11)}$ of R. Cronbach's alpha ranges from 0 to 1, where zero indicates the total absence of internal consistency of the items; and 1, 100\% consistency. Thus, the acceptable alpha values are between 0.70 and 0.90 , and item-total correlation values are acceptable when above 0.3 , which are adopted for the study ${ }^{(12)}$.

The validity of the data was done through exploratory factor analysis in the Factor, using the Diagonally Weighted Least Squares (DWLS) estimation method with polychoric correlation, suitable for polytomous data. The factors were extracted by means of Parallel Analysis, in which the correlation matrix of the raw data is computed, then a random set of correlation matrices is generated that replicate the structure found in the empirical matrix. From this point, the extraction of factors will occur through the verification of how many eigenvalues in the empirical data matrix present values higher than the simulated eigenvalues ${ }^{(14)}$. For that, Warimax Rotation was used, as it is a statistical procedure that makes it possible to reduce a large number of variables observed in a number of factors that represent the constructs or latent dimensions ${ }^{(15)}$.

\section{RESULTS}

The sample of university students was mostly female (70.1\%), with an average age of 23.8 years; $32.2 \%$, entering the quota system; and $54 \%$ with family income of up to one minimum wage. As for the distribution of the sample among the HEl courses, it was found that $27 \%$ were from Pedagogy, $22.8 \%$ from Administration, $21.5 \%$ from Biology, 15.2\% from Nursing and $13.5 \%$ from Rural Education.

The item-total correlation and Cronbach's alpha of the HPLP in university students are shown in Table 1. The scale demonstrated good reliability with Cronbach's alpha of 0.83 . The item-total correlation coefficients ranged from 0.233 to 0.522 , with the majority being considered ideal (above 0.3), and only items 01, 13, 19 and 20 were below this mark (being acceptable above 0.2). Therefore, as all indicators presented acceptable item-total correlation coefficients, all were maintained.

Through the sedimentation graph (Figure 1) of the Parallel Analysis, the reduction of the scale items in the factors was explored, which demonstrated a structure with two dominant factors, indicated by the vertical line.

The parallel analysis showed that the scale is suitable for a structure with two dimensions, since, in the scree plot, it is observed that the first and the second factor are responsible for a greater explained variance of the data (empirical) and were higher than the explained variance of the random data (simulated), being indicative of the existence of two factors responsible for most of the variance shared by the items (Figure 1).

From the graph, the first factor explained $28.69 \%$ of the variance and contains 15 items on the daily routine to promote health; the second factor explained $15.85 \%$ and contains five items on attitudes to avoid risks. Item 13 (Ingestion of eight glasses of water) in factor 1 and item 01 (Use of behaviors to avoid risks) in factor 2 presented factor loads below 0.3 , indicating that they may not be part of the latent trait. Thus, the correlation between the two factors also remained below 0.3. 
Table 1 - Cronbach's item-total and alpha correlation if item excluded for the Health Promotion Behavior Scale, of the Nursing Outcomes Classification, applied to university students, Floriano, Piauí, Brazil, 2016-2017

\begin{tabular}{|c|c|c|c|c|c|}
\hline Items & $\begin{array}{l}\text { Item-total } \\
\text { correlation }\end{array}$ & $\begin{array}{c}\text { Cronbach's } \\
\text { alpha if } \\
\text { excluded item }\end{array}$ & Items & $\begin{array}{l}\text { Item-total } \\
\text { correlation }\end{array}$ & $\begin{array}{c}\text { Cronbach's } \\
\text { alpha if } \\
\text { excluded item }\end{array}$ \\
\hline 01 & 0.294 & 0.829 & 11 & 0.522 & 0.819 \\
\hline 02 & 0.445 & 0.822 & 12 & 0.519 & 0.818 \\
\hline 03 & 0.460 & 0.821 & 13 & 0.242 & 0.832 \\
\hline 04 & 0.375 & 0.825 & 14 & 0.478 & 0.820 \\
\hline 05 & 0.423 & 0.823 & 15 & 0.469 & 0.820 \\
\hline 06 & 0.360 & 0.826 & 16 & 0.459 & 0.821 \\
\hline 07 & 0.507 & 0.820 & 17 & 0.341 & 0.827 \\
\hline 08 & 0.459 & 0.821 & 18 & 0.316 & 0.829 \\
\hline 09 & 0.443 & 0.822 & 19 & 0.284 & 0.830 \\
\hline 10 & 0.517 & 0.818 & 20 & 0.233 & 0.831 \\
\hline \multicolumn{5}{|c|}{ Cronbach's alpha of the scale } & 0.83 \\
\hline
\end{tabular}

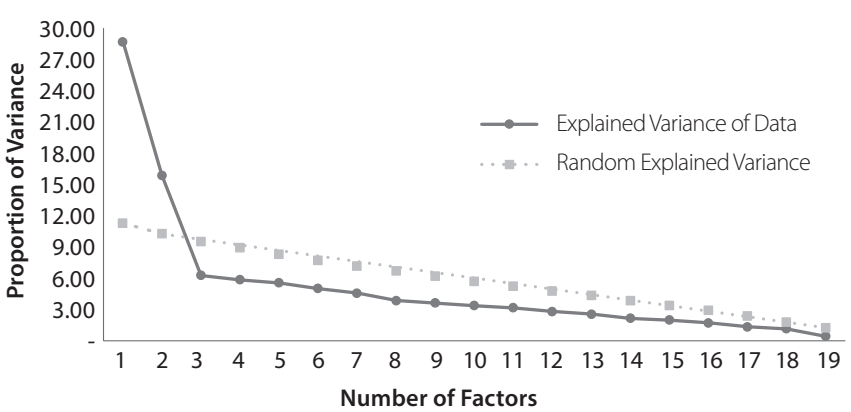

Figure 1 - Scree plot and parallel analysis of Health Promotion Behavior Scale of Nursing Outcomes Classification, applied to university students, Floriano, Piauí, Brazil, 2016-2017

Table 2 - Factorial loads of the items in the dimensions of the Health Promotion Behavior Scale, of the Nursing Outcomes Classification, applied to university students, Floriano, Piauí, Brazil, 2016-2017

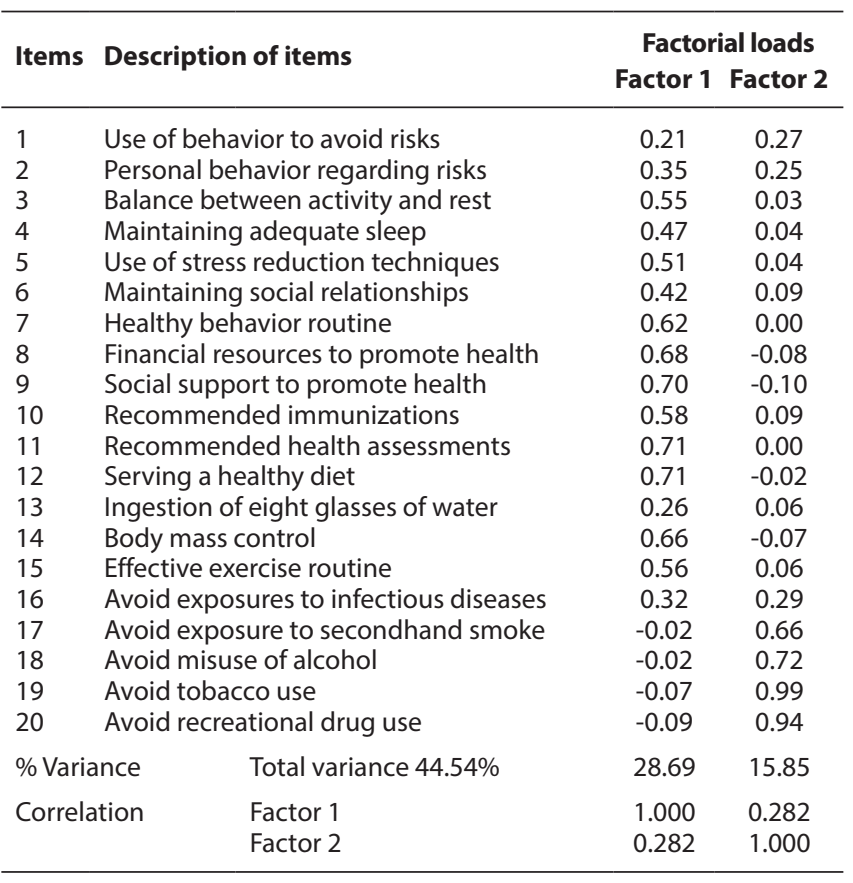

\section{DISCUSSION}

Nursing outcome criteria describe the status, behaviors, reactions and feelings of patients, professionals, family and community and, although initially developed to measure the responses of administered care, they can become assessment criteria that allow us to determine the behaviors, in this case, related to the health promotion of university students ${ }^{(16)}$.

The NO related to health promotion behavior proved to be an important ally in the evaluation of university students, as its indicators have constitutive definitions that are adapted to the moment of life of this public, and can be a link of care used by Primary Care nurses. In a historical perspective, the first edition of this NO is dated 1997, with a small revision in its definition in 2004, when the term "personal actions" was added ${ }^{(89)}$. In 2008, the indicator "Balance between exercise, work, leisure, rest and nutrition" was reformulated to "Balance between activity and rest", and four indicators were added: Maintenance of adequate sleep, Intake of eight glasses of water daily, Act to avoid exposure to second-hand smoke and Obtain regular check-ups ${ }^{(8-9)}$. In all editions, the primary references of the first edition were maintained.

The version of the HPLP that was tested in this study, despite not containing all the indicators, proved to be consistent in time and space from the reliability results obtained ${ }^{(17)}$. Through this psychometric property, a good Cronbach's alpha coefficient was observed, which reflects the degree of covariance between the items on the scale and its degree of homogeneity, being strongly influenced by the number of items in the instrument ${ }^{(18)}$. The Health-Promoting Lifestyle Profile II instrument, from which the HPLP indicators were derived, has been showing Cronbach's alpha between $0.87^{(11)}$ and $0.92^{(10)}$. Thus, drawing a parallel between the instruments, it is observed that, despite all the changes resulting from the use of HPLP-II items, as NO indicators and health promotion behavior in the NOC taxonomy, they maintain good internal consistency.

Contributing to the elucidation of reliability, the item-total correlations found show homogeneity and interconnection between items. In addition, a high correlation between the indicator and the total NO score indicates that the item contributes to increase the variance of the HPLP, helping the discrimination between subjects ${ }^{(18)}$. However, four indicators (01, 13,19 and 20$)$ obtained estimates below the adopted reference and need to be further investigated in future studies, since the low correlation can increase the error in estimating health promotion behavior. Therefore, it is understood that items with low correlation indicate little affinity with the others, and may not be part of the set of behaviors that make up the NO.

The factor analysis showed that HPLP is organized in the factors "Daily routine to promote health" and "Attitudes to avoid risks", showing that there is a possibility to evaluate health promoting behaviors in university students, taking into account the different dimensions of life.

The structure found is consistent with the proposition of taxonomy that envisions a multidimensional assessment of nursing phenomena. In this sense, it is interesting to note the difference in structural organization between the HPLP-II and the HPLP, since the NO indicators have been reconstituted into a two-dimensional structure, different from the six-factor structure of the HPLP-II widely validated in different contexts ${ }^{(11,19)}$. Thus, although the HPLP indicators were constructed by items from the six dimensions of the HPLP-II instrument, in the sample of 
university students, those from the Physical Activity, Nutrition, Spiritual growth, Interpersonal relations and Stress management were organized in a dimension, and items from the Health responsibility dimension comprised a second.

The indicators that anchored the first factor are related to the daily routine, aiming to promote health among university students. Among the items that make up this factor, are those related to behavior to avoid risk, activity and rest, sleep, stress reduction, immunization, weight control, healthy diet, physical exercise, exposure to infectious diseases, health assessment, social support, maintenance of social relations and financial resources.

Health promotion, reflected in a healthy lifestyle, is an integral part of disease prevention. Health promotion behavior has been associated not only with better physical and mental health outcomes, but also with lower health costs ${ }^{(20-22)}$. Thus, the evaluation of health promotion behavior is essential in research in order to provide data for preventive nursing interventions, facilitate the formulation of policies and enable people to self-manage their health behaviors ${ }^{(11)}$. However, it is suggested the need to review the item "Personal behavior to avoid risks", on the NOC scale, as it is a broad term that has caused difficulties in the clinical application of this indicator.

Still in this first factor, as an example of health promotion strategies, we have the balance between sleep and rest with daily activities, acting in the organization of the immune and humoral systems ${ }^{(23)}$. In addition to this immunological defence, there are vaccines, recognized as one of the most successful public health actions in Brazil, with a reduction in the occurrence of preventable diseases ${ }^{(24)}$. In addition, the role of stress in the immune system and its relationship, especially with chronic diseases, have already been $^{(25-28)}$. Thus, the indicators that assess these aspects proved to be valid and can be used in clinical practice by nurses with university students.

The indicators that assess weight control, healthy diet and physical exercise also make up the first factor of the scale, being closely related to lifestyle. These items appear constantly in the literature, strongly linked to the decrease in morbidity and mortality from cardiovascular diseases and cancer, and demonstrated clinical validity in this study ${ }^{(29-30)}$.

The indicators that evaluate aspects related to the social services extend the intersectoral issue to health promotion, in which social support, the maintenance of social relationships and financial resources need to gain space, either in the context of the systematization of nursing care, or in conjunction with other professionals and sectors of society, aiming to resolve health vulnerabilities. Thus, the Primary Care nurse can work on these indicators with the encouragement of the exercise of citizenship, the strengthening of family and community bonds and the performance of specific health promotion actions, raising the individual's empowerment as a multiplying agent of quality knowledge in health among peers ${ }^{(31)}$.

The indicator "Avoiding exposure to infectious diseases" anchored in the first factor, but with factor load sharing with the second, and can also participate in this. The wording of this indicator is similar to the set of those on attitudes to avoid risks, but with the difference of not having a well-defined behavioral command, holding it in the first factor. In these cases, it is important to see how the items behave in other validations so that the theoretical question is really confirmed.

In line with what has already been mentioned, it is necessary for young people to carry out periodic health assessments in order to establish self-care actions in the short, medium and long term, with nurses as an ally in this process, since Primary Care nurses have a fundamental role in maintenance of health, since they act in the longevity of human beings through global health promotion actions and have a specific role in preventing diseases in groups at risk ${ }^{(32)}$.

Indicators for assessing drug use showed validity and reliability. These results are considered important, as admission to the university has been understood as a critical period, with greater vulnerability for the beginning and maintenance of the consumption of alcohol, tobacco and other drugs, and this scenario should be the target of actions promoting health ${ }^{(33-34)}$.

The use of alcohol and other drugs is a contemporary public health problem, which has aroused intense concern in the international context. Drugs can cause physical and psychological dependence, in addition to other damages such as accidents, suicide, violence, unplanned pregnancies, transmission of diseases, also showing themselves as a risk factor for chronic noncommunicable diseases and their complications. In addition, consumption ends up favoring trafficking and, as a result, the increase in crime, especially in large urban centers ${ }^{(35)}$.

It should be noted that two indicators ("Ingestion of eight glasses of water" and "Use of behaviors to avoid risks") presented low factor loads and did not anchor in any of the factors, pointing out that they may not be part of the latent trait contained in HPLP. Thus, other studies in similar or dissimilar samples should test these indicators, so that they can show whether they really have validity to compose the $\mathrm{NO}$ and the health promotion behavior. Furthermore, it is important to emphasize that the psychometric properties of the instrument are not static, and may vary according to the change in the study population. Other factors that can also influence the assessment of psychometric properties lie in the mode of administration (interview, telephone or self-application), the type of target population, the sample size, among others ${ }^{(36)}$.

NO validation studies contribute to the decision making and assistance provided by the nurse, as important indicators for the patient's clinic are used and those that are not relevant to their health situation are eliminated. The use of classification systems in nursing must be put into practice through validation studies, in order to ensure greater reliability and accuracy to the practice of nursing, in addition to contributing to the autonomy and decision making of nurses in the face of health situations ${ }^{(37)}$.

\section{Study limitations}

As a limitation that needs to be considered in this study, the similarity of some items of the original scale is pointed out, which resulted in exclusion for better understanding of university students. It was also difficult to compose the sample with students from more advanced periods, since university meetings become less frequent as a result of academic internships. However, despite this limitation, it is important to note that an adequate sample size was used to assess the psychometric properties of the scale. 


\section{Contributions to the area of Nursing, Health or Public Policy}

The study brings advances for nursing, as well as for public health as a whole, by clarifying the validity and reliability of a technology to measure health promotion behavior in university students. It also contributes to validate this scale in other audiences in order to improve the quality of care provided and, thus, promote health-friendly behaviors. It also offers assistance for the revision of the referred NO, favoring the taxonomy of the NOC.

Validation studies must be disseminated in the field of nursing in order to contribute to the development and improvement of knowledge and clinical practice. The use of nursing classifications in health promotion improves practices and facilitates the achievement of satisfactory results, in addition to contributing to the strengthening of the area as a science.

\section{CONCLUSION}

The health promotion behavior scale showed evidence of good reliability and validity, demonstrating that it can be applied to the population of university students to assess the profile of these behaviors, as well as serve as a basis for building strategies to improve the quality of life of this public.

It is recommended to use the scale in new studies, with different methodological designs, in the area of planning and monitoring health care and services. It is also indicated to carry out confirmatory factor analyzes that consolidate the results of this study, since the use of the classification systems in nursing, in scientific research, helps its consolidation and provides the valuation of the practices and knowledge specific to the area for its greater coverage in the universe of public health.

\section{REFERENCES}

1. Back IR, Dias BC, Batista VC, Ruiz AGB, Peruzzo HE, Druciak CA, Marcon SS. Fatores de risco para doenças cardiovasculares em universitários: diferenças entre os sexos. Ciên Cuid Saúde. 2019;18(1). doi: 10.4025/cienccuidsaude.v18i1.40096

2. Ferreira FMPB, Brito IS, Santos MR. Health promotion programs in higher education: integrative review of the literature. Rev Bras Enferm. 2018;71(Suppl 4):1714-23. doi: 10.1590/0034-7167-2016-0693

3. Lopes R, Tocantins FR. Health promotion and critical education. Interface Comun, Saúde, Educ [Internet]. 2012 [cited 2020 Feb 1];16(40):23548. Available from: https://www.scielosp.org/article/icse/2012.v16n40/235-248

4. Sampaio JF, Dantas CCDBL, Porto VFA, Cavalcante JC, Medeiros ML. A extensão universitária e a promoção da saúde no brasil: revisão sistemática. Rev Portal: Saúde Soc. 2019;3(3):921-30. doi: 10.28998/rpss.v3i3.5282.

5. Tomás CC, Queirós PJP, Ferreira TDJR. Comportamentos promotores de saúde: propriedades psicométricas de um instrumento de avaliação. Texto \& Contexto Enfermagem. 2015; 24(1), 22-29. doi: 10.1590/0104-07072015000700014

6. Piovesan LR, Schimith MD, Simon BS, Budó MDLD, Weiller TH, Brêtas ACP. Promoção da saúde na perspectiva de enfermeiros de atenção básica. Rev Enferm UERJ. 2016; 24(3):5816. doi: 10.12957/reuerj.2016.5816

7. Cestari VRF, Florencio RS, Moreira TMM, Pessoa VL, Barbosa IV, Lima FE, Custodio IL. Nursing competencies in promoting the health of individuals with chronic diseases. Rev Bras Enferm. 2016;69(6):1195-203. doi: 10.1590/0034-7167-2016-0312

8. Moorhead S, Johnson M, Maas ML, Swanson E. Nursing Outcomes Classification (NOC):measurement of health outcomes. 4th ed. Philadelphia: Elsevier, 2010.

9. Moorhead S, Johnson M, Maas M. Classificação dos resultados de enfermagem (NOC). 5 ed. Porto Alegre: Artmed; 2013.

10. Sousa P, Gaspar P, Vaz DC, Gonzaga S, Dixe MA. Measuring Health-Promoting Behaviors: Cross-Cultural Validation of the Health-Promoting Lifestyle Profile-II. Int J Nurs Knowl. 2014;26(2):54-61. doi: 10.1111/2047-3095.12065

11. Kuan G, Kueh YC, Abdullah N, Tai ELM. Psychometric properties of the health-promoting lifestyle profile II: cross-cultural validation of the Malay language version. BMC Public Health. 2019;19(1):751. doi: 10.1186/s12889-019-7109-2

12. Barrientos-Trigo S, Gil-García E, Romero-Sánchez JM, Badanta-Romero B, Porcel-Gálvez AM. Evaluation of psychometric properties of instruments measuring nursing-sensitive outcomes: a systematic review. Int Nurs Rev. 2019;66(2):209-23. doi: 10.1111/inr.12495

13. Almeida MDA, Seganfredo DH, Unicovsky MR. Validação de indicadores da classificação dos resultados de enfermagem para pacientes com problemas ortopédicos. Rev Esc Enferm USP. 2010;44(4):1059-64. doi: 10.1590/S0080-62342010000400029

14. Çokluk Ö, Koçak D. Using Horn's Parallel Analysis Method in Exploratory Factor Analysis for Determining the Number of Factors. Educ Sci: Theor Pract. 2016;16(2):537-51. doi: 10.12738/estp.2016.2.0328

15. Lourenção DCA, Tronchin DMR. Clima de segurança em centro cirúrgico: validação de um questionário para o cenário brasileiro. Rev Eletrôn Enferm. 2018;20. doi: 10.5216/ree.v20.47570

16. Rodríguez-Acelas AL, Cañon-Montañez W, Mantovani VM, Figueiredo MS, Silva MB, Almeida MA. Resultado de enfermagem para avaliação da dor após artroplastia de quadril. Rev Cuidarte. 2019;10(2):e651. doi: 10.15649/cuidarte.v10i2.651

17. Souza ACD, Alexandre NMC, Guirardello EDB. Propriedades psicométricas na avaliação de instrumentos: avaliação da confiabilidade e da validade. Epidemiol Serv Saúde. 2017;26:649-59. doi: 10.5123/S1679-49742017000300022

18. Pasquali L. Psicometria: teoria dos testes na psicologia e na educação. Editora Vozes Limitada; 2017. 
Validity of Nursing Outcomes Classification health promotion behavior scale in college students Pacheco HSA, Borges JWP, Furtado AM, Rodrigues MTP, Mascarenhas MDM, Brito LCS, et al.

19. Sousa P, Gaspar P, Vaz DC, Gonzaga S, Dixe MA. Measuring Health-Promoting Behaviors: Cross-Cultural Validation of the Health-Promoting Lifestyle Profile-II. Int J Nurs Knowl. 2014;26(2):54-61. doi:10.1111/2047-3095.12065

20. Choo J, Kang H. Predictors of initial weight loss among women with abdominal obesity: a path model using self-efficacy and healthpromoting behaviour. J Adv Nurs. 2015;71(5):1087-97. doi: 10.1111/jan.12604

21. Mikkelsen K, Stojanovska L, Polenakovic M, Bosevski M, Apostolopoulos V. Exercise and mental health. Maturitas. 2017;106:48-56. doi: 10.1016/j.maturitas.2017.09.003

22. Myers J, Doom R, King R, Fonda H, Chan K, Kokkinos P, Rehkopf DH. Association between cardiorespiratory fitness and health care costs: the veterans exercise testing study. Mayo Clinic Proceedings. Elsevier. 2018;93(1):48-55. doi: 10.1016/j.mayocp.2017.09.019

23. Magalhães NL, Braga VA, Silva FMS. Avaliação da qualidade do sono em idosos atendidos em uma clínica escola de fisioterapia. Rev Interdiscip [Internet]. 2019 [cited 2020 Feb 2];12(2):44-52. Available from: https://revistainterdisciplinar.uninovafapi.edu.br/index.php/ revinter/article/view/1503/pdf_419

24. Bisetto LHL, Ciosak SI. Análise da ocorrência de evento adverso pós-vacinação decorrente de erro de imunização. Rev Bras Enferm. 2017;70(1): 87-95. doi: 10.1590/0034-7167-2016-0034

25. Cormanique TF, Almeida LEDFD, Rech CA, Rech D, Herrera ACDSD, Panis C. Chronic psychological stress and its impact on the development of aggressive breast cancer. Einstein. 2015;13(3):352-6. doi: 10.1590/S1679-45082015AO3344

26. Gómez JHD, Duque LNH, Palacio JJC. Modelos de predicción de riesgo cardiovascular. Med UPB. 2017;36(2):153-60. doi: 10.18566/medupb. v36n2.a08

27. Eddy $\mathrm{P}$, Heckenberg R, Wertheim EH, Kent S, Wright BJ. A systematic review and meta-analysis of the effort-reward imbalance model of workplace stress with indicators of immune function. J Psychosomatic Res. 2016;91:1-8. doi: 10.1016/j.jpsychores.2016.10.003

28. Santana Á, Mendes K, Silva C, Costa J, Andrade R, Barbosa H, Teixeira I, Ribeiro W. Fatores de risco para doença arterial coronária em docentes de uma faculdade privada do interior da Bahia. 2019;9(3). doi: 10.17058/reci.v9i3.13198

29. Amann VR, Santos LPD, Gigante DP. Associação entre excesso de peso e obesidade e mortalidade em capitais brasileiras e províncias argentinas. Cad Saúde Pública. 2019;35:e00192518. doi: 10.1590/0102-311X00192518

30. Lacombe J, Armstrong MEG, Wright FL, Foster C. The impact of physical activity and an additional behavioural risk factor on cardiovascular disease, cancer and all-cause mortality: a systematic review. BMC Public Health. 2019;19(1):900. doi: 10.1186/s12889-019-7030-8

31. Ferreira CPS, Marques JF, Rozendo CA, Ferreira CB, Pinto LMTR, Ferreira AS. Estratégias pedagógicas para educação em saúde com adolescentes: uma revisão integrativa. Rev Pesqui: Cuid Fundam. 2016;8(2):4197-211. doi: 10.9789/2175-5361.2016.v8i2.4197-4211

32. Marcus-Varwijk AE, Peters L, Visscher T, Smits C, Ranchor A, Slaets J. Impact of a nurse-led health promotion intervention in an aging population: Results from Community Health Consultation Offices for Seniors. Int J Integrated Care. 2018;18. doi: 10.1177/0898264318804946

33. Silva EC, Tucci AM. Padrão de consumo de álcool em estudantes universitários (calouros) e diferença entre os gêneros. Temas Psicol. 2016;24(1):313-23. doi: 10.9788/TP2016.1-21

34. Fernandes TF, Monteiro BMDM, Silva JBM, Oliveira KMD, Viana NAO, Gama CAPD, et al. Uso de substâncias psicoativas entre universitários brasileiros: perfil epidemiológico, contextos de uso e limitações metodológicas dos estudos. Cad Saúde Coletiva. 2017;25(4):498-507. doi: $10.1590 / 1414-462 \times 201700040181$

35. Ribeiro WA, Andrade M, Cirino HP, Teixeira JM, Martins LM, Mariano ES. Adolescência, tabaco, álcool e drogas: uma revisão no olhar preventivo da educação em saúde na ESF. Rev Pró-univerSUS [Internet]. 2018 [cited 2020 Feb 2];9(1):02-06. Available from: http://editora. universidadedevassouras.edu.br/index.php/RPU/article/view/1115

36. Coluci MZO, Alexandre NMC, Milani D. Construção de instrumentos de medida na área da saúde. Ciên Saúde Coletiva. 2015;20:925-36. doi: $10.1590 / 1413-81232015203.04332013$

37. Araújo JNDM, Fernandes APNDL, Silva ABD, Moura LA, Ferreira Jr MA, Vitor AF. Validação clínica do comportamento de prevenção de quedas em ambiente hospitalar. Rev Bras Enferm. 2018;71(4):1841-9. doi: 10.1590/0034-7167-2017-0212 